Beyaz bir kağıt aldım ve önüme koydum. Sanki büyük bir eskiz yapmaya karar vermiştim sonunda. Sanki hiç bitmeyecekmiş gibi. Elimde kalın 6B eskiz kalemi vardı eski günlerdeki gibi. İlk başta Kağıt boştu ve üzerinde hiç birşey yoktu. Gerçekten çok zordu ustamın anısına bir șeyler çizmek. Bir işaret koymak bile meseleydi. Zaman geldi ve başladım çizmeye, döne döne, geriye ileriye giderek kelimelerle. Yıllar üzerinden yine bereberce yolculuk yaptım onunla. Anlar ve anılar ip gibi sıraland,, sisler içindeki geçmişte.

Ne öğrendim, ne öğrendik hocadan! Güzel Sanatlar Akademisi dediğimiz İstanbuldaki okulun, efsanevi Boğaz kıyısındaki mabedinde, sanat mıydı, mimarlık mıydı öğrendiğimiz. Hepimizin ayrı bir hocası olmasına karşın eminim

onun aracılığ 1 ile yaşamın gerçek mimarlığının sanatıyla ilgili farklı farklı bazı sırlar bulduk. Kelimelere dökmeye çalışıı̆ıım bu eskiz işte böyle bir senaryoyu çizmeyi hedefledi bizim unutulmaz hocamız, Akdenizli ve İstanbullu bir usta, bir mimar Muammer Onat için.

Summary: I took a white paper and put it in front of me. As if I decided to make a big sketch at the end. As if it will never finish. I had a

tick, $6 B$ sketch pencil in my hand, like good old days. The paper was empty and there was nothing first. It was really very difficult to draw something for the memory of my Master. Even to put a mark was a challange. And time came, I began to draw by going back and front retrospectively with the words. In the end, I traveled with him over the years. The memories and moments lined up in a row in the foggy past. What have I learned, what have we learned from him! Was it 'art' or 'architecture' which we learned in a legendary temple, a school called Fine Arts Academy of Istanbul. Yes we did, both. But it was more than that, far more than that. Although the 'hoca' of every one of us was different, I am sure that through him we all have found some

clues of the secrecy of the art of real architecture of life. That is what the sketch is intending to draw for our unforgetable teacher, a Mediterranaen and an Istanbulian Master, an architect,

Muammmer Onat.

Anahtar Kelimeler:

Mimarlık, Mimari Tasarım, Mimari Tasarım Eğitimi.

Keywords: Architecture, Architectural Design, Architectural Education

\title{
"Aynalarin Dansi"
}

Dr. Hüseyin YANAR, Mimar (IDGSA)
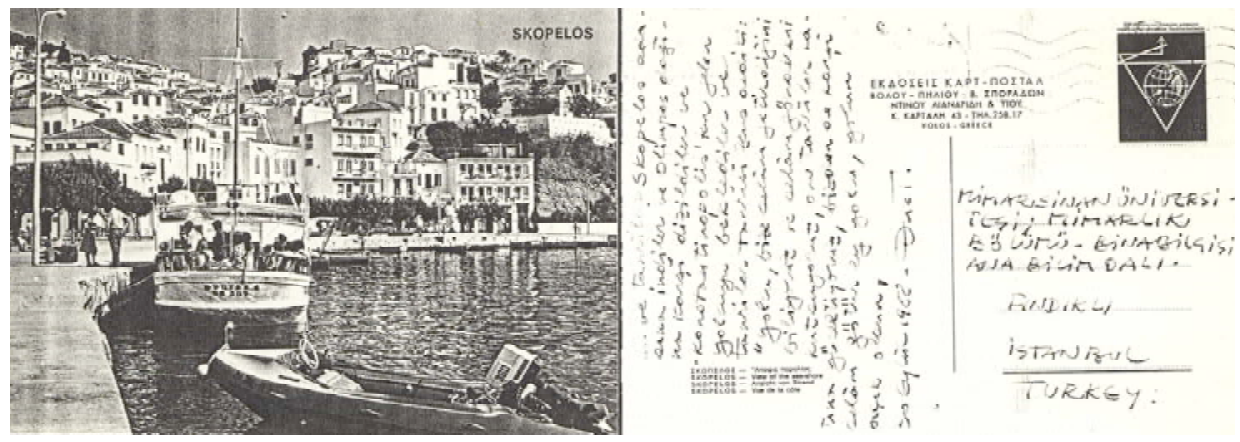

...Ve Tanrılar Skopelos adasına indiler ve Olimpos dağına karşı dizildiler ve Konstantinopolis'ten gelen yolcuyu beklediler ve Tanrılar Tanrısı Zeus dedi ki: Yolcu, bize selam getirdiğini biliyoruz, ve selam göndereni tanrılar katına yüceltiyoruz, bizden de karşıya selam götür ey yolcu, yolun açık olsun. 30 Eylül 1982. M. Onat

Hoca için yapılacak toplantı kesinleşip adımı konuşmacılar arasında görünce, bir de üstüne üstlük daha sonra bir yazı yazmam istenince çok telaşlandım. Uzun süre hiç bir şey yazamadım. Hiç yazamayacă̆ımı sandım. Tanıyanlara değil de özellikle onu tanımayanlara, yeni nesillere anlatmak, o anları yazıya aktarmak çok zordu. Hoca ile yaşanmışlıkları, yaşamak gerekirdi. Onu sözlerle, cümlelerle yan yana getiremedim nedense. Soyut bir resim gibi olmalıydı ne anlatacaksam, ne yapacaksam diye düşündüm. Bire bir olmamalıydı. Bunu yapmak da kolay değildi. Keşke çok iyi piyano çalsaydım, karşısına geçseydim, bir klasik müzik parçası yapsaydım ve hocamı notalarla anlatsaydım. Ne tür bir örgü ya da örgüler olurdu, ne şekilde, hangi motifleri kullanırdım, ritmi, tempoyu nasıl seçerdim, nasıl sıralardım notaları hoca için!

Çaresiz, etrafımdaki izlere bakmaya başladım. Parça parça duyguları, düşünceleri yan yana koymaya, içgüdüsel bir çizgi ya da çizgiler oluşturmaya, bir yandan da farklı renkleriyle, parçalarıyla bir kolaj yapmaya karar verdim. Sanki onun bize mimarlığı anlattığı gibi hikayelerle, anekdotlarla onu resmetmeye koyuldum. Sanki eski günlerde, hocanın atölyesinde olduğu gibi büyük bir eskiz kağıdını önüme aldım ve kalınca bir kalemle, sanki sözlerle çizermişçesine 
yazmaya başladım. Kitaplığım aklıma geldi. Onun özel köşesindeki bir bölüme ulaşmıştım. Karma karışık yı ğınlarının arasında, beyaz dosyalara koyduğumu hatırladı̆̆ım, yılları bir araya getiren, benim eski dünyamdaki bazı izler, önümdeydi. Kim bilir nerelerde, hangi duygularla yazdığım satırlar arasında düşüncelere daldım. Bunlara bir bir bakarken, hocamı orada, sayfalar arasında tekrar aramaya başladım.

\section{Zorba}

Dosyaların birkaç sıra üzerindeki rafların birinde, yine her nedense kitaplıklarımda olan, o ülkeden bu ülkeye, oradan oraya yıllardır taşıdığım bir önemli kitap, Kazancakis'in Zorba'sı geldi önüme. Kitap önümde, Zorba ile ustası bir adada, karanlıkta ateş yanmış, rakılar içiliyor, kafalar hafif dumanlı, Zorba yavaşça ayağa kalkıyor ve o ünlü dansı başlıyordu ateşin etrafında. Anlamlı dansı, belki de kendini oynadı̆̆ 1 , kendini anlattığı dansı. Hocanın çok sevdiği Yunan adaları, Kalambaka, daha ilerisi, ikinci okulu olarak nitelediği, İtalya ve Çizme'nin Ortaçağ kentleri, oraların yazarları çizerleri ve diğerleri, hocanın sevdiği Kuzey'in Akdenizlileri gibi Finli mimarlar, onunla birlikte olduğumuz yıllar, kürsü, Akademi, atölye, hocalar, öğrenciler, dostlar, eskiler, yeniler, orası, burası hepsi sıralandı Zorbanın dansında.

\section{Anlar}

Önümde duran rastgele seçtiğim dosyalardan birini elime aldım, yavaşça açtım. Karaköy'deki İşkembe Lokantası'nın birkaç resminin sararmış fotokopileri düştü önüme.

Hani, hocanın, işkembe lokantasının sahibi, ustası ve orada çalışanlarla konuşa konuşa yaptığı, bittikten sonra keyifle zaman zaman gidip çorbasını içtiği, sonra da bir gün önünden geçerken yerinde artık yeller esen o lokantanın sahibinin değiştiğini ve tabelasının biracıya dönüştüğünü görerek, bir konferansta konuşmasını başına eklediği “....ve anladım ki işkembeci ölmüştü” dediği, Karaköy İşkembecisinin Architecture Forms Functions'da (1969 / sayı 15) yıllar önce yayınlanan tasarımı. Uzun mekânın sonundaki davlumbazları, üzerlerinde dövme bakır kaplamaları ve yuvarlatılmış tezgahlarıyla bizi sanki tarih kokan bir mekana, masalarıyla, sandalyeleriyle sahil kasabalarına doğru götüren, bu öğeleri modern havada yorumladığı meşhur çorbacısı. Kenarlarından parlayan ışıkları ile içeri çekilmiş, üzerindeki düzenli
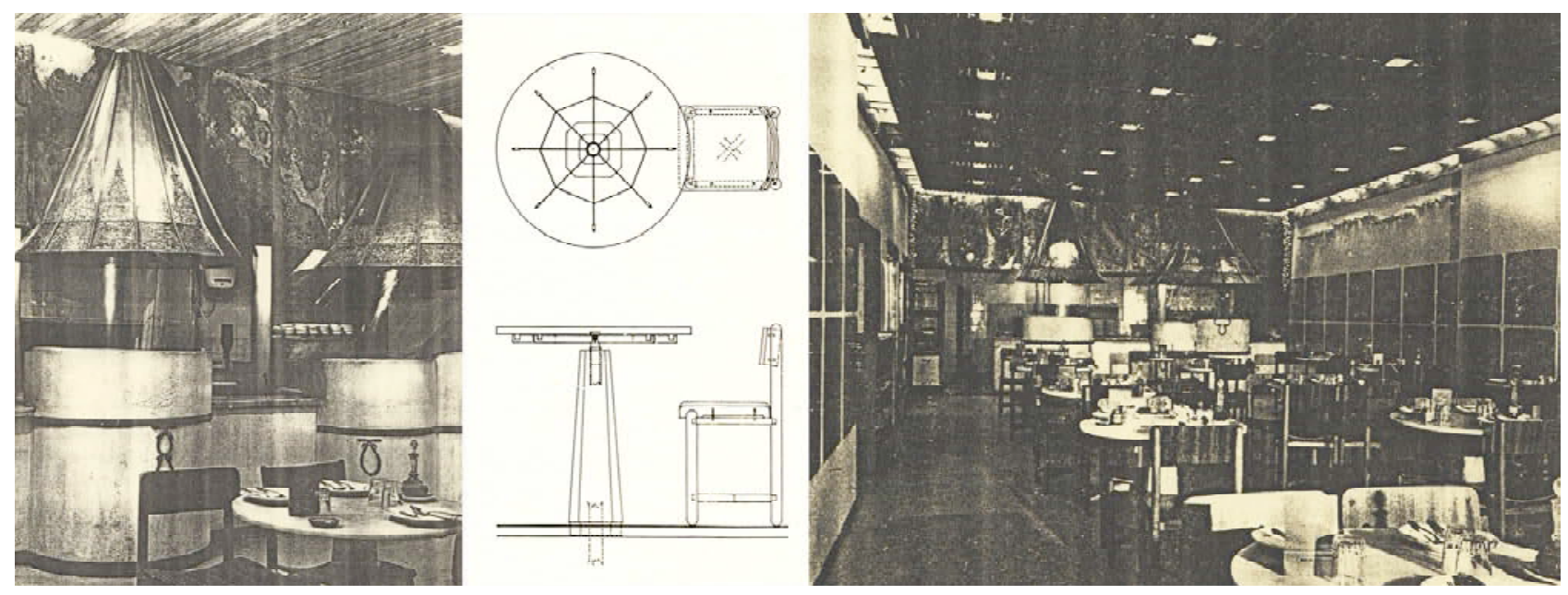

42 Özel sayı 2, Ekim 20II 


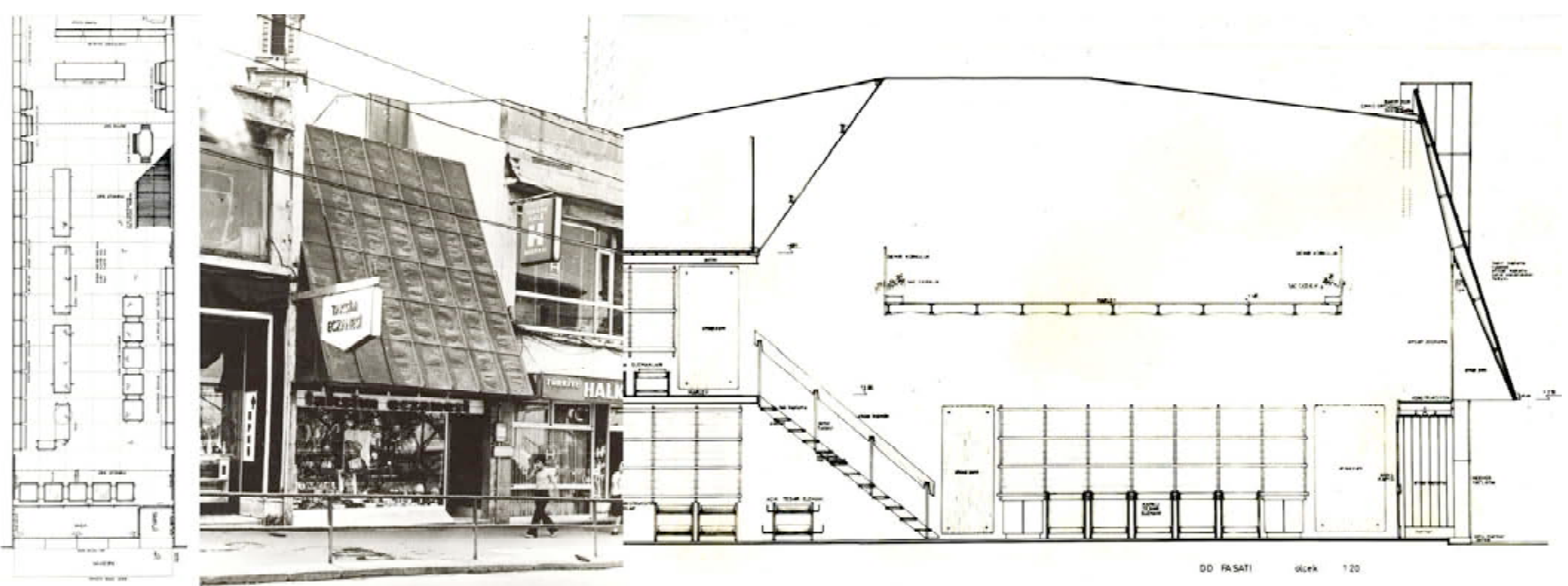

noktasal lambalar ile yukarıda, havada gibi duran ahşap tavanın altında kim bilir kimlere ev sahipliği yapmış masalar örtüleri ile peş peşe sıralanıyordu.

Ve arkasından bir başka nirengi noktası, Taksim'den Beyoğlu'na doğru yürürken, solda binaların arasında cesaretle ama saygı ve mütevazılık ile çatısını alttan geçenlerin üzerine eğmiş özgün bakır çatılı Taksim Eczanesinin bazı imajları geldi. Narin kesiti, hocavari detayları ile yıllar öncesinden anlamlı bir tasarım. Yanlarına dıştan takılmış ayakları ile parça parça sıralanarak uzunlamasına planda yüzen tezgahların ve arkalarındaki aynı sistemdeki ilaç raflarının ana giriş mekanındaki düzeni, yukarıda önce arkadaki üst kata ve sonra demir profillerle yine yüzen bir asma kata varan uzunlamasına merdivenler ve hocanın dapdaracık zor bir yerde yarattığı dünya, etkili, gelip geçenlere selam veren çatısının altında bir iç dünya önümdeydi.

Yine bir özel sohbetimizde Ruhi Su içintasarladı ̆̆ 1 ortası yarılmış, sanatçının yüreği yarılmış gibi tasarladığı anıt mezarının projesi için yaptı̆̆ım bir yorum üzerine söylediği bir cümleyi yazmışım bir kenara. Hoca için çok özel bir mimar eski bir usta Yunan Aris Konstandinidis'in Baumeister'de yayınlanan birkaç oteli, hocanın Yunanistan'a yolculuğunda bir

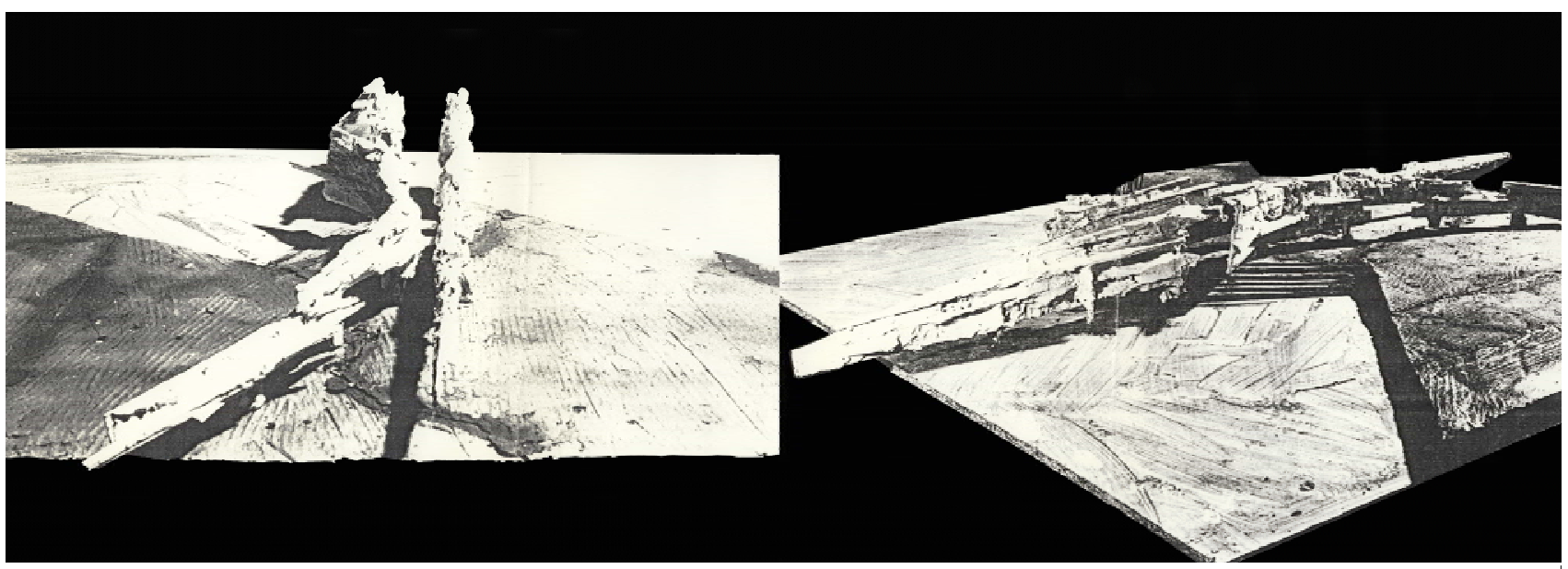


otelin girişindeki duvara çakılan panoda mimarın adını gördüğünde paylaştığı heyecanı, yine kendisi için özel olan mimarlardan Carlo Scarpa, Candilis ve hocamın hoca dediği Alvar Aalto ile ilgili bazı kitaplardan kopyalar, yorumlar, petrol bunalımı öncesi dünyayı kasıp kavuran metabolist mimarlarla ilgili Japon mimarisi ile ilgili sohbetlerden bazı notlarım. Ve diğerleri.

Ve uzun seneler önce bir öğle sonrasında, hocanın heyecanla bana fotoğraflarını göstererek anlattığı, eski rektörümüz sevgili Tamer Ağabey (Başoğlu) ile yaptıkları Kıbrıs Türk şehitliği geldi birkaç resmi ile. Bir timsah gibi kaidesinin üzerinde Türkiye'ye doğru yönelmiş dev, muhteşem bir heykel. Altında gezilip dolaşılan, sanki peyzajını kendi yaratan, içinde yaşanılacak gibi, girip çıkılan, keşfedilmeyi bekleyen organik, dinamik bir yapit.

1990 in başında, Mimarlar Odası tarafından düzenlenen, benim ve Mete Hoca'nın ve Nurdoğan Özkaya Ağabey ile birlikte söyleşiye katkıda bulunacaklar arasında olduğum Mimarlığg Öğretmek başlıklı konuşmasının davetiyesinde yazılan özgeçmişinden iki önemli satır, "Dünyadaki en büyük isteği, 1952 yılında, Güzel Sanatlar Akademisi Mimarlık Bölümü'nden mezun olmasıyla gerçekleşti" ile "Bugüne kadar hep gençlerle bulunduğunu her şeyini onlara borçlu olduğunu ifade ediyor" cümleleri, çat kapı, hafta sonu olmasına karşın gittiğim hocaların Dragos'daki yazlık evinde doktoramla ilgili sabah başlayıp akşama kadar süren bir günden anekdotlar, yazdığım her satırını özenle okuduğu, yorumlar yaptığı doktoramdan bir sürü sayfalar.

44 Özel sayı 2, Ekim 20II
Sevgili dostum, Ayhan (Böyür) ile öğrenciyken, hocaya yardım ettiğimiz Burdur'daki halı pazarını çizerken sağa sola yazdı̆̆ım bazı anekdotlar, tam girişteki galerili, yüksek açık arttırma yeri, kanyaklı kahveler, 1sıta ısıta içtiğimiz vermutlar, bir gece yarısı perspektifini çizmeye çalıştığım, Üsküdar Meydanı Yarışmasıyla ilgili düşünceler, Mimar Sinan'ın Mimarlık Fakültesi'ndeki şimdi çatıya çıkan uzun merdivenin başından çıkılan, Orta Aydınlığa düşündüğü dört kollu, ama içerideki dört narin kolonun aşağıdaki zemin kata, iki kat boşlukta zıpkın gibi indiği kürsü, hep beraber tamamladığımız Salıpazarındaki okulun uzantısıyla ilgili proje teklifi, kim bilir hangi park için nerede yapıldı̆̆ını alçak duvarlar üzerinde ağaç dallarının yayılmasını andıran çeşme projesi ile ilgili krokiler, yıllarca önce Edremit'te yaptığg duvarları ritmik bir şekilde zigzaglar çizerek giden, doktoramda da kullandığım yağ fabrikası, bir okul gezisinde uğradığımız, Akçay'da tasarladığı iki eviyle ilgili yazdıklarım, öğrencilerle beraber olduğumuz yıllarda tashihlerden bazı yakalayabildiklerim, özel cümleler, özel yazılar oradaydı.

\section{YöK}

İşte bir not daha. "YÖK geldi..." diye yazmışım başına. Ve altında da bazı yorumlar. Hocanın o gürültüde söylediği bir söz.

1980'lerin başlarındaydık. Sanki aniden, fırtınalı bir gecenin ardından tartışmalarıyla YÖK adım adım geliyordu. Bütün yüksek öğretim her kademesi ile etkilenmişti. Sonrasında, vizeler, okuldan atılmalar başladı. Hepimiz zor durumdaydık. Ben o zaman asistandım, hocanın asistanıydım. Bir süre sonra asistanlığımın adı değişmiş, bir sürü meslektaşım gibi araştırma görevlisi olmuştum. Güzel 


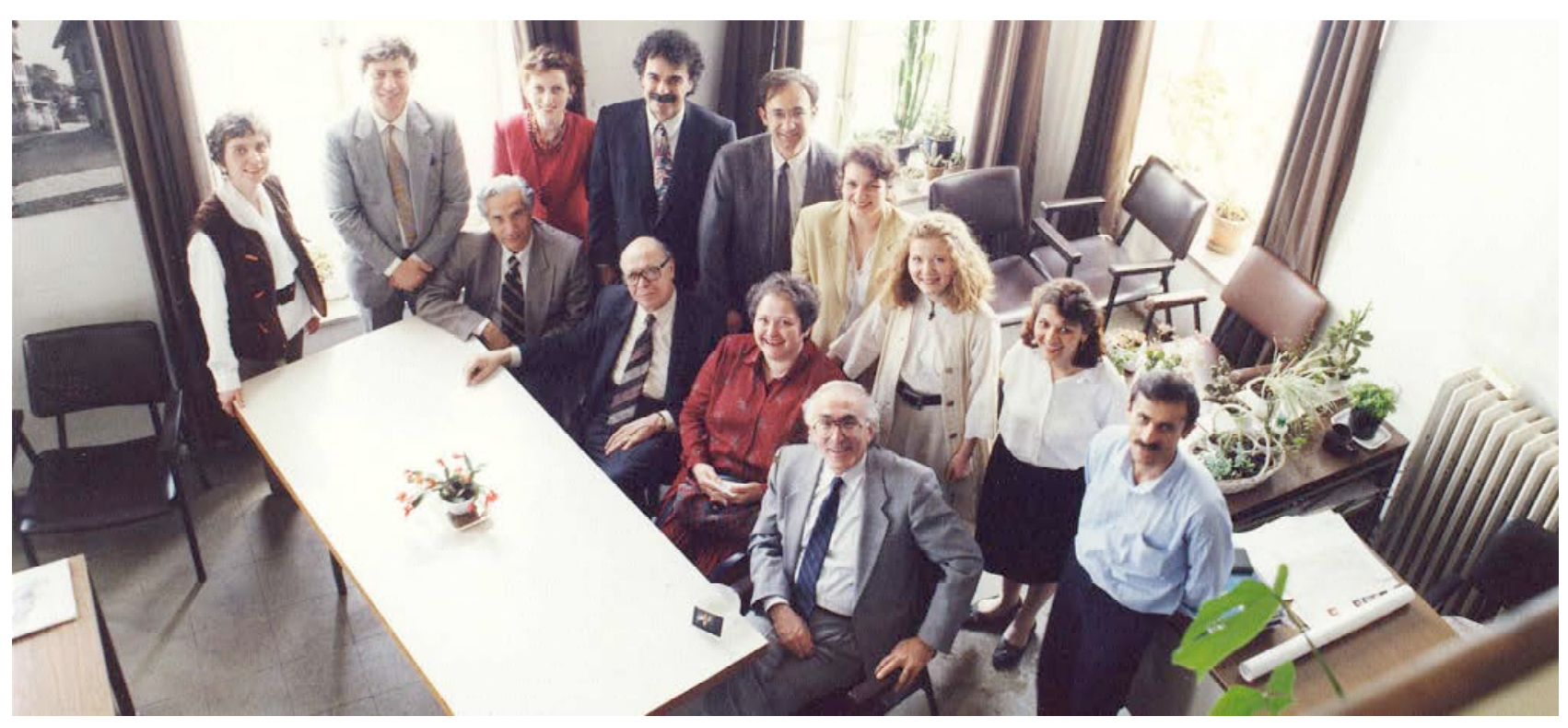

Sanatlar Akademisi'nin adı da değiştiriliyordu. Hocanın bir gün çok özel bir cümle söylediğini hatırlıyorum. Onu yazmışım. "Hepimiz paltomuzu alıp gitmeliyiz. Öğretmenler, öğrenciler bütün okul. Yeni insanlar, yeni hocalar, yeni öğrenciler gelmeli”. Bu yeni bir düzen, yeni bir sistem, başka bir şeydi.

Gerçekten de öyle oldu. "Ne olursan ol, yine de gel", benzeri söylemler, Türk insanının tam kalbine giden sözler, yı ̆̆ınları etkilemişti. Kavgalardan yorgun ve yılgın Türkiye'ye, yeniden değişim vaat ediliyordu. Sivil yönetimden vazgeçilen yılların hemen arkasından gelen yıllardı. Farklı eğilimler bir araya getirilmiş, abartılı köşeler, düşünceler alabildiğince pahlanıyordu. Tam bir toplum mühendisliği işi idi ve sanki ince ince düşünülmüş, pazar araştırılması yapılmış, mimarlık deyimi ile bir proje ortaya sürülmüştü.

Bugün artık aramızda olmayan, pop müziğinin efsanevi ismi, Cem Karaca'nın bile, kendisinden bir zamanlar alınan vatandaşlığ 1 bu atmosferde geri verilmiş ve ülkesine dönmüştü. Yine bir efsane, halterin altın çocuğu, cep herkülü Naim Süleymanoğlu Avustralya'daki kamptan kaçırılmış, daha sonradan açıklandığına göre Bulgarlara önemli bir para ödenerek, Bulgaristan'dan Türkiye'ye transfer edilmiş, müthiş heyecan ile karşılanmış, ayyıldızlı forma ile rekorları altüst etmeye devam etmişti. Bütün bunlara paralel, köşe dönme sloganları ile paranın çokça konuşulmaya başlandığı yıllar. Bazı özel okullar da bu gürültüde açıldı. Para ile her şey satın alınabiliyordu. Dünya Şampiyonları bile, Bulgarların elinden Naim'i bile. Kapı açılmıştı.

Bir yandan şeffaflık, açıklık derken hem öğretimde, hem de akademik kademelenmede tepeden gelen yeni kurallar, yasaklar konmuştu. Hocalar da, öğrenciler de köşeye sıkıştılar. En çok zarar görenlerin başında da atılma korkusu ile kendilerini kapı dışında bulacak öğrenciler geliyordu. Gerçekten de birçoğumuzun yaşadığı o yıllar Türkiye'de bazı şeyleri değiştiren ve bizleri bugünlere getiren parametrelerin konulduğu, her zaman çok tartışılan yıllar olmuştu. Geçen 25 senede yeni bir nesil böyle bir dönemin rüzgarıyla yetişti, 
yetiştirildi. Bizden önceki nesil ile bizimkinin uzantısı oldu. Akademide, atölyelerde sabahlandığı projelerin yapıldı̆̆ı yıllar 1970 öncesi, '70 sonrası bizim okulları bitirdiğimiz '80'ler sonrasıydı. Sonraki '90'ları ve ötesini etkileyecek bir dönüm noktası olmuştu. $\mathrm{Bu}$ kırılma noktasında eğitim de etkilendi, eminim hoca da, belki de hocanın öğretisi de, öğretmedeki arayışları da; Hoca da, önündeki öğrenciler de, öğrencilerin özgün hikayeleri de, hepimiz de. Hoca aynıydı ama bu her döneme bağlı önüne gelen öğrenciler farklıydı, projeler de. Hocanın da bundan etkilenmemesi mümkün olamazdı.

\section{Hayaller}

Hemen arkasındaki sayfaların birinde önemli bir notu İngiltere'de iken almışım. '90'lı yıllara girmeden üç, dört ay önce YÖK'ün o ünlü, bilgi görgü arttırma maddesi ile burada başladı ğım doktoramı yapmak için üç yıllığına yurtdışına gitmiştim. Daha sonra atölyelerinde proje hocalığı yapacağım Oxford Mimarlık Okulu'nda olduğum ilk günlerde oradaki öğrenci seçme sistemi başlığının altına maddeleri ile alt alta 4 satır yazmışım. Aynen şöyle:

“1) Paranız olmalı, 2) Portfolyonuz olmalı 3) 3 kişilik jürinin değerlendirmesini aşmalısınız, 4) Psikoloji sınavından geçmelisiniz".

O yıllarda para ile ilgili olan madde ve psikoloji sınavı ilginçti. Birincisinde okul ilk bakışta bir market ya da ticarethane hissi veriyordu. Hoca ile para konuşuyordunuz. Paranız yoksa her şey bitiyordu. Dördüncü maddede vurgulanması istenen ise belki de sinirlerinizin çelik gibi sağlam olması gerektiği idi. Bunun için de o sıralar orada görev yapan sonradan meslektaşım olan müthiş güzel bir insan, Yunan asıllı bir İngiliz, her zaman pozitif duruşu ile öğrencilerin kalesi, sevgili Byron Mikaellides'in Mimari Psikoloji sınavının aşılması lazımdı. Mimarinin aslında Boing kullanmak gibi ciddi bir iş olduğu vurgulanıyordu belki de. Dedikleri mimar olduktan sonra doğru olabilirdi (hatta o bile su götürürdü de...) ama aslında kanımca okullarda hayaller, rüyalar öğretilmeliydi. Çünkü öğrencilik, bunların çalışma yaşamı öncesi belki de yapılacağı tek yerdi. "Antrenmanda atılan gol, gol sayılmaz" Hoca o yıllarda bunu böyle diyerek formüle ederdi belli ki. GS'nin bir zamanlar Avrupa'da Altın Ayakkabı alan ünlü golcüsünden alıntılanan, “Tanju gole gidiyor” ise bir başka parolamızdı kürsüde, atölyede her şey yolunu bulduğunda gülümseyerek söylerdik kim bilir kaç kez.

Ciddi, asık suratlı bir eğitim yerine gülen, şakalarla, hikayelerle dolu bir dünya yaratılmalıydı. Fantezilerin önlerini kapamak değil önlerini açmak olmalıydı hedef, çizgilerin arasında. Nasıl özgür ve cesur olmaları gerektiğini öğretmeliydik. Benim yıllardır hem öğrenci olarak hem de atölyesinde asistanı olarak kendisinden hissettiğim, aldığım, hep yanımda taşıdı ğım ve daha sonra gerek burada gerekse başka ülkelerde öğrencilerle paylaşmaya çalıştı̆̆ım en önemli şeylerden biri de bu olmuştur. Tabii herkesin ayrı bir Muammer hocası vardı ve aldıklarını kendi alt yapısı ve mizacıyla da birleştirerek seçiyordu. İlerideki kariyerinde yorumluyordu. Zaten bir ömür boyu etrafımızdaki izleri takip etmiyor muyduk? İstediğimizi alıp, istemediklerimizi görmeden geçmiyor muyduk, etrafımızdaki bunca işaretin arasında. 


\section{Atölye}

Atölyede, masanın iki yanında, her hoca ile karşısında oturan her öğrencinin arasında her zaman uzaklıkları, yakınlıkları farklı bir mekan vardır. Muammer Hoca ile bu mekanın sınırları genişlerdi. Hatta bu yok olurdu. Bunu hissederdiniz. Masanın etrafı yuvarlanır, çember genişledikçe genişler, zaman kavramı durur, tashih geç vakitlere, karanlıklara doğru akar, ders derslikten, not notluktan çıkar, atölyeden kendi köșelerinize taşınan çabanız bütünüyle, tamamen kişisel bir uğraşa, hobiye dönüşürdü her bir öğrenci için. Hoca öğrenci karşı karşıya değil de yan yana olurdu, birbirlerine güvenirlerdi. Öğrenci, her an hocasına ulaşabilme fikrini taşırdı kafasında. Bu da çok önemliydi.

Zamanı geldiğinde, atölyede birleştirilerek büyütülmüş masanın etrafında, hikayeler döküldüğünde, kat kat masanın üzerine biriktiğinde zaman gelir herkes bir tarafını alır, projesine katar ve yola devam ederdi. Sabırlıydı hoca. Beklerdi. Hiç usanmadan beklerdi. Sanki yıllar varmış gibi projeyi yapmak için. Projede bir yerlerden başlardı sonunu bilmediğiniz heyecanlı bir serüvene doğru. Herkesin ayrı bir anı, ayrı bir başlangıç noktası vardı. Sanki zaman yoktu, sömestre yoktu, y1l yoktu hocanın atölyesinde. Bardak taşacak derdi ve taştığında siz sizdiniz. Zamanı gelirdi ve bir kez yapacaksınız derdi. Ondan sonrası kolaydı. Saygı başka parametrelerde girerdi atölyenin kapısından. Çaylar gelir giderdi Ahmet Amcadan. Sigaralar içilirdi, eskiden yasak olmadığında.

Geleneksel mimarlık atölyelerindeki programdan doğan, metrekare bölüşümlerinden başlayan ve binaya ulaşan süreç çalışmazdı orada. Klasik sistem altüst olurdu. Herkes için diğerlerinden farklı bir başlama noktası vardı her serüvene başlamak için. Özgür çizgiler akardı çoğu kez paftalara, bir öğrenci alır, diğeri devam eder gibi. Hoca susar, öğrenciler tashihe devam eder, hoca onları gözler, top sanki birinden diğerine giderdi, halka olmuş grupta. Dört kollu merdivendeki inişin güzelliğini, eğik çatıları, kadın modasının sırlarını, ilahi eksenleri, kentte evde ya da bir başka planlamada kuralları koyan aksları, yuvarlak masanın sırlarını, Romeo ile Juliet'i, Aziz Nesin'in “Bir Şey Yap Met"ini ve daha binlerce hikayeyi tashihlerde ondan öğrendik.

Hep aklınızda kalacak sizinle taşıyacağınız anlamlı sözler, bazen ciddi, çoğu kez arkasında başka şeyler anlatan gülümseten sözler vardı hocanın dolmakalemle yazdığı cümlelerde. Hapishane sonrası, aftan yararlanıp tekrar okula dönen bir öğrenci arkadaşa yazdığı, "Potin bağı ile fiyaka olmaz Necati", çizdiği ev planında müthiş atraksiyonlarla, ama lüzumsuz üst kata çıkan Okan'ın kağıdının köşesindeki "Çıktın da ne oldu”, yine bir Bina Bilgisi tashihinde kendi evini çizen bir öğrenciye yazarak sorduğu "Bandırma vapuru nereden kalkıyor", Üsküdar'da proje yapmak isteyen ama ne yapacağını bilmeden hocanın önüne oturan Gökhan'ın kağıdına sıraladığ 1 "Üsküdar meydanında şapka yapmak büyük iştir azizim”, ya da bir öğrencinin kendini keyiflendirdiği abartılı bir tasarımı için yazdığı "Eli kaçmış" cümlelerinde olduğu gibi...

\section{Çizmek}

"El ile kafa arasında" diye yazmışım bir sayfanın başına... Bitmişlik değil belki de bitmemişlik esastı çizgilerde. Noktayı koymak değil, koyduktan sonrası 
önemliydi. Ucu açıklık önemliydi. Özgün hikayelere bağl çizgiler, eskiz ve pelür kağıtları üzerinde her yerdeydi. Herkes bir yanda sanki kendisiyle baş başa, meditasyon yapar gibi çok çizerdi, çizgilerle antrenman yapardı. Ama bir tashih gününde, aynı masada, çizgilerin arasında, oldukça donanımlı bir arkadaşımız projesini hocaya gösterirken söylediği cümlesi anlamlıyd, bir tarih gibiydi. "Elim kafama erişmiyor" demişti. Hocanın cevabı şaşırtıcı oldu. "Mimar olmanız için çizmeniz gerekmez

Şeyciğim”. Bu kadar yıl çizgilerin arasında onları fal bakar gibi okumaya çalışan hocanın bu sözü bizi düşündürmüştü. Ama anlamı da açıktı. Mimarinin bir kafa işi olduğuydu, kafada bittiğiydi. Çizgiler, aslında bir araçtı ve herkesinde özel kişisel çizgileri ve anlatımı vardı, olmalıydı. Bir başka yönü ile belki de binlerce mimari arasından kendinize göre bir mimari seçebilirdiniz ya da mimariyi, kendi mimarinizi istediğiniz gibi tanımlayabilirdiniz. Çizerdiniz, çizmeyebilirdiniz; ne kadar isterseniz.

\section{Projeler}

Öğrenciyken, Akademi'de hocanın eski yaptırılan projelerle ilgili açılan bir sergisinde gördüğümüz organik tasarımlar, akvaryumlar, şaraphaneler, yağhaneler, hatta metabolistik yaklaşımlar, bizim dönemlerde daha başka biçimde yine tez değeri olan projelere doğru gitti, daha sonra da bunları kentsel kararların öne çıktığı, binaların boşlukların bütünde belirlendiği, buna göre yer bulduğu, nirengi noktalarının hikayeleri belirlediği projeler takip etti. Yapılan volümlerle, boşluk ve doluluklarla, eklerle ana eksenler, ana nirengi noktaları belirginleştiriliyordu. Camiler, yollar, meydanların oluşumu ve yayılımı gibi.
Farklı kent okumaları, kent deşifrasyonu yapiliyordu bir anlamda. Koca kentler avuç içine dönüşmüştü. Ya da başka projeler, konutlar, evler kentlere dönüşüyor, boşluklarıyla doluluklarıyla başka bir ölçeğe geçiliyordu. Her şey her şeye dönüşebilirdi. Bu da ölçeğin, ölçek fikrinin soyut bir anlamda ele alınmasıyla ilgiliydi. Tabii anında yakın plan yapmak ya da çok gerilere gitmek yani ölçeği hızla değiştirmek başka kapılar açabilir, farklı şeyler gösterebilirdi. Her şey bambaşka anlamlar kazanabilirdi.

Osmanlı, Bizans, Roma, öncesi sonrası ve arkeoloji bir başka temaydı projelere giren. Tarih her zaman projelerde bir altyapı olmuştu tabii ama, gelenekseli korumakla, konserve etmekle çok uğraşmayan, onu yepyeni bir biçimde yorumlamayı hedefleyen bir anlayış vardı stüdyoda. Bir kısmı yıkılmış eski fabrikalar yepyeni ekler alıyor, roman, tiyatro, dans, müzik ve bir sürü farklı disiplin bazı projelerin motoru oluyordu. Duvarlar, o akan duvarlar, özgürce inen çatılar, akan binalar bir başkaydı her zaman. Bugünün o sinekkaydı, her şeyi bitmiş, hep gerçek, hayale hiç yer bırakmayan bilgisayar imajlarının ön versiyonlarının ve soğuk aydıngerin neredeyse hiç giremediği bir stüdyoda, pelür kağıtlarına, eskiz kağıtlarına çizilen, gerçeğe dönen eskizler, hayale yer birakan, donmayan eskizler vardı.

\section{Tezler}

Mimaride tez yapma ile proje yapma uğraşı arasında benzerlikler olmasına karşın temelde büyük farklılıklar görülebilir. Biri kısaca yazma, diğeri çizme eylemidir. Biri kitaplar, kitaplıklar arasında geçer, diğeri her türlü çizimler arasında (kafada, kağıtta, elle, bilgisayarla vs.) Tabii ikisinde de araştırılır, hatta çok da 


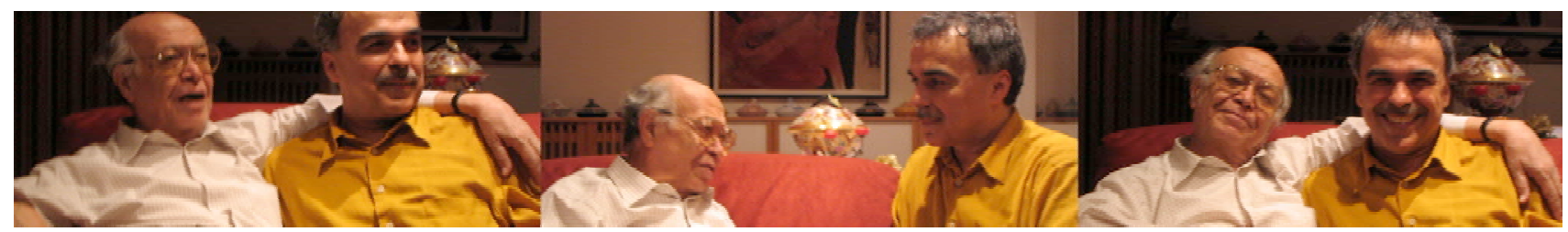

çizilebilir ama yöntemleri farklıdır, terminolojileri, metodolojileri farklıdır. Özellikle tasarımla uğraşan, mimarinin tasarım tarafına, proje yapma tarafına ilgi duyan kişilerde diğer tarafın diline adapte olmak kolay olmaz. Sonuçta bu bir transformasyon işidir ve teknikler başka bir tekniğe adapte edilir.

Hocanın proje yaptırma ve tez yaptırma yöntemleri arasında paralellikler vardır. En önemlisi de projede ve tezde bütünü düşünme fikri temel alınır. Hocanın öğrencilerinin çoğu zaten tasarım tarafı kuvvetli kişilerdir. Atölyedeki çizme temposu bu defa yazma tarafiyla aynı üslupta geliştirilir. Hikayeler hikayeleri kovalar, her şey her şeyin içindedir. Bütün bu projelerin, tezlerin birçoğunda ortak bir şeyler vardır. Mimarlık dediğimiz uğraş, proje çizme veya tez yazma yoluyla eskizlerle veya yazmalarla sanki kendi kendinize kaldığınız, vermeniz gereken hoş bir savaşa döner gider, belki de mimarlığın da çok ötesine gider.

Hoca ben doktoramı tamamlamaya yakın yıllarda dekan olmuştu. Doktoram ile ilgili konuşmaları çoğu zaman odasında yapardık. Keyifli anlardı. Bu sırada kağıtlar, imzalar arasında sohbetlerimiz devam ederdi. Bir gün, bir şeyler imzalarken "Sana vasiyetimdir, ileride hiç bir idari görev almayacaksın" demişti şaka yollu, bir yandan da çok ciddi. O zaman anladım ki, atölyesindeki mimarlıkla ilgili dünya, o dünyanın ötesi, derinlikleri bütün bürokratik kuralların çok uzağındaki başka bir yerdi.

\section{Profesör}

Bir not daha... "Don Juu ve Ustası"... İngiltere'deyken çok yakın bir mesai arkadaşım olmuştu. Kore'den bizim bölüme katılan, Kore'deki Pusan Üniversitesi Mimarlık Fakültesi'nde görev yapan Prof. Don Juu Woo. Benim yaklaşımlarımı biraz uçarı bulur, bu da hoşuna gider, kendisi başka türlü düşünse de çok desteklerdi. Önemli şeyler paylaşmıştık. Ben yaşlardaydı. Ben ona hep nedense Mr. Profesör derdim. O da bana bir gün yemekte gülerek niye bana Mr. Profesör diyorsun demişti. Ben de ona, sen benim gördüğüm en önemli profesörlerden biri olduğun için demiş ve gülmüş̧ük. Ama bölümde herkes ona Mr. Profesör deyince ismi de öyle kalıp gitmiş̧ti orada kaldığı sürede. Bir gün özel sohbetimizde ona hocamı anlatmıştım. İlgiyle dinlemiş, benim böyle bir hocam olmadı demişti. Ama onun da bir ustası ("master"i) olduğunu söylemişti. Bana kendi ustasını anlatmıştı. Ustasının bir mimar olmadığını anlamıştım. Ustası bir "Monk"tu; dağda bir manastırda yaşayan bir rahipti. Bizim Mr. Profesör de zaman zaman onunla konuşuyor, onunla paylaşıyordu. Hatta doktorasının birçok yerini orada düşünmüş, yazmış ve orada, dağda bir kulübede ailesinden ayrı bitirmişti. Zaman zaman da ona uğrardı. Ben hocamla, yani ustam ile onun ustasını yan yana koyduğumda, ya da iki resmi yan yana getirdiğimde her ikisinde de ortak bir şey, bir benzerlik dikkatimi çekti. Muammer hoca bana göre mimarlı̆̆ın arkasına giderdi. Hayatın deneyimleri 
arasında gider gelirdik. Sanki mimarlık ile yaşamı birbirine sarardı, sarmalardı. Sanki "mimarlığınızı yaşama eksenine oturtun" derdi. Bunu direkt söylemezdi tabii, ya da ben böyle anlardım ya da anlamak isterdim. Mr. Profesörün ustası ise mimarlıktan belli ki anlamazdı. Ama yaşamı bildiği için, deneyimi olduğu için mimarlıktan da konuşabilirdi. Mr Profesör ustasının dediklerini yorumlayabilirdi, ustası da onun. Yaşamın en büyük erdemi olan insan ilişkilerine çok önem veren iki kişi idiler hoca ve Don Juu Wuu'nun ustası. Bunlar okullarda çok öğretilmez ama hoca bu eksende gidip gelirdi mimarlığı konuşurken. Mimarlık yaşam için bir renkti ve araçtı onun için sanki.

\section{Ve Jane}

Bir başka sayfada, başka bir satır. "Jane, Rhowbotham ve 'Su'lu bir Stüdyo”.

Oxford Mimarlık Okulu'ndaydım. Bir jüriye davet edilmiştim. Dönem ortası jürisiydi. Beni çağıran 1. sınıfları organize eden oradaki hocalardan Jane Tankard ve öğrencilerle gün boyu, işlek bir yolda altı dükkan üstü konut programlı proje çalışmalarını değerlendirdik, hep birlikte çok da güldük. Ben keyif almıştım. Günün sonunda o zamana kadar hiç tanımadığım Jane de ortamdan memnun olmuş olacak ki, bana bize katılır mısın deyince tereddütsüz kabul demiştim.
Karşımda bana 20'ye yakın öğrenci, Jane'in kendi grubu ve bunlardan başka diğger iki grup öğrencileri türlü şekillerde motive etmeye çalışıyorduk. Bazen Jane ile grupları bir araya getiriyorduk.

Öğrencilerle birlikte gittiğimiz, incelediğimiz sanatçıların sergileri, Mona Hatum'lar, Anish Kapoor'lar, Saatchi Galerileri, kesip inceleyip stüdyoya taşıdı̆̆ımız filmler, Carlos Saura'lar, Carmen'ler, bir sürü farklı malzemeler, kablolar, boyalar, mumlar, metaller, camlar, bozuk radyolar, plastikler, akla ne gelirse, ne buldularsa, etrafından akarsuların geçtiği, Oxford'un merkezine yakın büyük bir çayır ve başta koyduğumuz Su kavramı, orada ev olarak kullanılan nehir tekneleri, tarihi pub, metruk fabrikalar, konutlar alt alta üst üste gelmişti. Dinamik, her stüdyo günü workshoplarla, hocanın ve öğrencinin ayrı ayrı attığ1 adımlarla, karşı sorulara, karşı cevaplara ve tartışmalara dayalı bir ortam yaratmaya çalışmıştık. Bu peyzaj içinde herkesin ayrı hikayesi vardı projelerde.

Sonunda da ilgi çekici işler çıktı, oldukça olumlu reaksiyonlar almıştık. En önemlisi de öğrenciler keyifliydi bu sürprizlerle dolu stüdyonun sonunda.

Programla, mekan listesiyle başlamayan, sona doğru mekanlarını bulan bir stüdyo oldu giderek. Baştan bunu bile planlamamıştık. Sanki hiç bir şey bilmek istemeden, beyaz bir kağıtla başlamış,

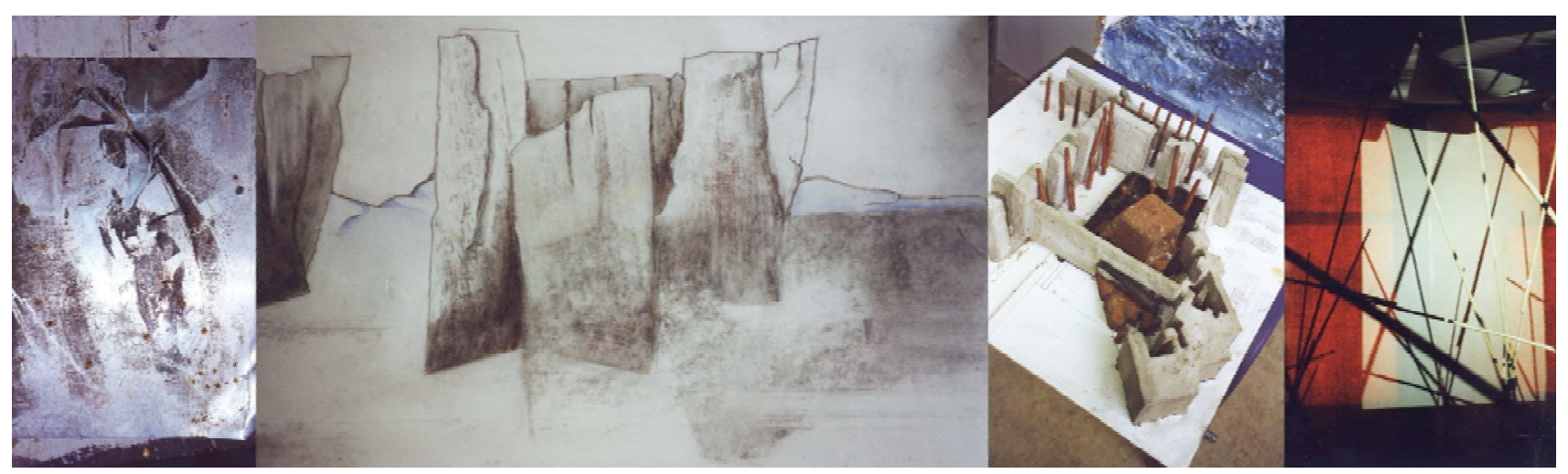

50 Özel sayı 2, Ekim 20II 
sonunda spontane adımlarla, ama sonradan gelişigüzel olmadığını anladığımız, öğrencilerin ve hocaların tamamen kendi deneyimlerinden yola çıkarak berraklaştırdığımız, (daha sonra bu anlayışı çok farklı gruplarla, farklı formlarda Finlandiya'da da denemiştim) bir stüdyo olmuştu. Jane ile iyi anlaşmıştık. Bir sohbette Jane bana, sen öğrencilere bir şey söyleyince, hah ben de öyle düşünüyorum diyorum demişti. Ben de sen aynı şeyi yaparken öyle düşünüyorum karşılığını vermiştim ona. Kısacası aynı gezegenden geldiğimiz açıktı ve aynı dili konuşuyorduk. Stüdyo bittiğinde bana hocasının bir kitabını hediye etmişti. Hocasının, İngiltere'de oldukça tanınmış bir isim, Kevin Rhowbotham olduğunu anladım. Kitabının başlığ 1 "Form to Programme" yani "Formdan Programa" idi. Bitmeyen, ucu açık, hayale açık projeler, bina gibi olmayan binalar, tasarımlar vardı sayfalarında. Ben de gülümseyerek çok eski yılları ve hocamı hatırladım. Hiç bir şey tesadüf değildi.

\section{Okuldaki Okul}

"Okul içindeki okullar" diye yazmışım hoca dosyasının bir yerlerine. Hocayla ilgili oraya buraya atladığım bu anılarla geriye dönüp, tekrar bizim Akademi'ye, atölyeler dünyasına baktığımda, sanki hemen karşımdaki bir tablonun parçaları yan yana gelmeye başlamıştı.

Bizim Akademi'de, Mimarlık Bölümü’nün Güzel Sanatlar Atölye Sistemi, hocaların farklı eğilimlerinden oluşan çizgileri ile belirleniyordu. Yan yana gelen atölyelerdeki farklı nüansların büyük önemi vardı öğrenci için. Herkes kurada çekerdi istediğini eğer şansı varsa. Bazı öğrenci arkadaşların "cepheci, cepheden başlatır" dedikleri bir hocamız, silgi ile tashih yapan bir diğer hocamı, her zaman şeker hocamı, detaycı hocamı, fonksiyoncu hocamız, okulu kuran hocamız, sert hocamız, sanatkar ve müthiş çizen hocamız, öğrenci babası hocamız ve bunların farklı eğilimleri bir mozaik oluştururdu önümüzde. Bir tarafta geleneksel mimarinin uzantısı eğilimler, bazen onlardan ayr1, modernist hatta sonraları postmodern yaklaşımlar ve daha da ötesi bazı farklı nüanslar. Bu yaklaşımların kökleri Sedat Hakkı Eldem, Arif Hikmet Holtay, Mehmed Ali Handan, Halit Femir gibi önceki dönemin Akademideki önemli hocalarına kadar giderdi. Mozaik niteliğindeki bu sistemin içinde bazen sistem kendiyle hesaplaşır, jürilerde öğrencilerin gözü önünde, ya da toplantılarda çatışmalar yaşanırdı. Örneğin o zamanlar, Nihat Hoca ile Asım Hoca'nın bir jüri sonrası, şimdilerde "Orta Hol” olarak tanımlanan yukarıdaki orta boşluğa doğru çıkarlarken yaptıkları tartışma farklı dünyaların tartışmasıydı öğrencilerin önünde.

Bir atölyedeki eğilim öğrencileri o kalıba koyar, yapilan projede kim hangi atölyeden geliyor anlardınız. Hangi hocanın etkisi olduğu da hissedilirdi. Muammer hocanın atölyesine gelenlerin de belirgin bir üslupları olurdu. Zamanla eskizsel anlatımları daha bir gelişirdi; iyi de çizerlerdi genellikle ama bunun yanında atölyedeki öğrenciler, birbirinden çok farklı kafaların bir araya geldiği bir platform oluştururdu çoğu kez ve farklı şeyler yaparlardı. Ayrıca bu atölyeyi seçenler genelde nereye gittiklerini bilirlerdi. Y1l, sömestre, kaldım geçtim orada yoktu. Onlar bir yandan nasıl olsa giderdi. Öğrenci olarak bu nüanslardaki renklerin arasında slalom yaparken, kendi mimarlığımızla, gelecekteki 
mimarlığımızla ilgili çizgiyi çizdiğimizi bilmezdik. Tek bildiğim, içgüdüsel olarak bir şeyleri seçtiğimizdi. Bu da sonradan anladığım gibi en doğru seçimlerdi. Ama "Güzel Sanatlar" geleneğindeki usta çırak ilişkileri sadece stüdyolarda hoca öğrenci arasındaki ilişkide değil, ileride hocaların hangi yolu seçecekleriyle ilgili seçimlerinde de belirgin olabilirdi. Tablo çok açıktı. Bizim okulda, yurt dışında da çoğu kez olduğu gibi okulun içinde okullar vardı, farklı farklı eğilimlere bağlı. Herkes de bu adaların üzerinde yürürdü. Ya da kendi adasını bulurdu.

Hocanın bu mozaikteki en önemli yeri, atölyesindeki eğitimde, yöntem olarak temelde mimari eğitimin pedagojik tarafıyla ilgilenmesiydi. Öğrenciyi bir şekilde motive ederken kendi yolunu açması için de cesaret verirdi. Bunun içinde kendi doğruları değil, öğrencisinin doğruları önemli olurdu. Öğrencilerin özel deneyimleri önemliydi. Oradan yola çıkar, genel geçer doğrularla hareket etmezdi. Her şeyin ötesinde öğrencisine güvenir ve öğrenci de bunu hissederdi. Öğrencisi her aradığında onu bulurdu. Hoca, öğrencilerinin çoğu şeyin üzerinden atlamasını isterdi. Buna cesaretlendirirdi. Hoca, mimarlığı tanımlamak için tashihlerde bazen öğrencilerin kağıdına bir + (artı) yazardı. Belki de herkesin farklı mimarlığının olmasından, mimarlığın çok geniş bir spektrum içinde görülmesinden ve farklılıklarla dolu bir çeşitlilikten söz ederdi. Belki de benzer şekilde güzellik yarışmalarına dönüştürülen mimarlık dünyasının, önümüzdeki dünyanın eleştirisi vardı sözlerinde.

Hocalığı, hoca merkezli bir sistemden öte, öğrenci merkezli bir eğitim sisteminin yanındaydı. Bunda da tek tip olmayan, standart olmayan öğrenci yetiştirmek ana

52 özel sayı 2, Ekim 2olı esastı. Mimariyi de yaşamın eksenine, tam ortasına oturtmuştu. Bunlar hocanın proje yapma sistemindeki çok çağdaş yorumlarıydı.

\section{Yönlendirenler}

Yazı uzadıkça uzuyor. Finale doğru gitmeliyim. Toparlamalıyım. Hoca ile ilgili beyaz dosyaları yerlerine koyarken, hala aklımda, notlarını aldığım üç ayrı başlı̆̆ı, üç ayrı fragmanı, sağa sola serpiştiriyorum.

Yönlendirenlere her zaman önemli görevler düşer. "Mimarlık Eğitimine Yön Verenler" de bu bağlamda önemli ve anlamlı bir başlık. Ama yine de oradaki ince noktaya, belki farklı biçimde okunabilir olabileceğine de dikkat çekmek istiyorum, ben öyle okumak istemesem de. Eğer gücü seviyorsanız, güçlü olmayı seviyorsanız, gerçekten istiyorsanız ve paranız varsa mimariyi ve hatta onun eğitimini yönlendirebilirsiniz. Yeni gündemler yaratabilirsiniz, medyasıyla, eğitimiyle, hatta okuluyla, okullarıyla, odalarıyla, farklı kuruluşlarıyla. Hele mimarlık, alanı ve satanı, alışı ve satışı ile bir ticaret aracı olur ise, CEO'ları, reklamcıları, pazarlamacıları ile yönlendirilebilir. Pazarı da bulunabilir. Fakat tabii eminim bu diziye daha sonra katılacak bir sürü isim olabilir ancak hocanın bunlarla uzaktan yakından hiç bir ilgisi olmamıştır. Bu yüzden, ben kişisel olarak hocayı, mimari ve mimarlık eğitimini yönlendiren bir kişi olarak değil de (tabii bu da vardır, ögrrencileri yolu ile başka bir okuma ile bu bir anlamda doğru da sayılabilir) mimariye gönül veren bir kişi olarak büyük harflerle başlıklamak istiyorum. Çünkü benim bildiğim hoca, yıllar yılı o köşesinde bizim anladı̆̆ımız anlamda mimarlığın pratik tarafını da, onun alasını da hem yapmış hem de öğrencisine bütün 
incelikleri ile öğretmiştir ama doğrusu öncelikle mimariye gönül vermeyi ve onu sevmeyi öğretmiştir. Bu adeta onun temel misyonu olmuştur. Bu da bir mimar adayına verilecek en büyük hediyedir.

\section{Minun Puoli}

Şimdi de adeta bir parantez açıp çok özel bir kanala giriyorum. Fincede özel bir deyiş vardır. 'Minun puoli'. Minun kelimesi, 'mina' dan gelir.

\section{Yine Zorba}

Tekrar Zorba kitabının sayfalarını karıştırıyorum. Yıllar önce okuduğum Kazancakis'in baş kitabında bir kaç doruk noktası vardır. Sanki bütün orkestra buralarda coşar ve finale gider. Kitapta, sonradan ustası olacak kişi Zorba'ya, adasına giderken rastlar ve yanında çalışmaya razı eder. Zorba bir hayat adamıdır. Ustası ise bir entelektüel. Ustası Zorba' dan çok şey öğrenir,

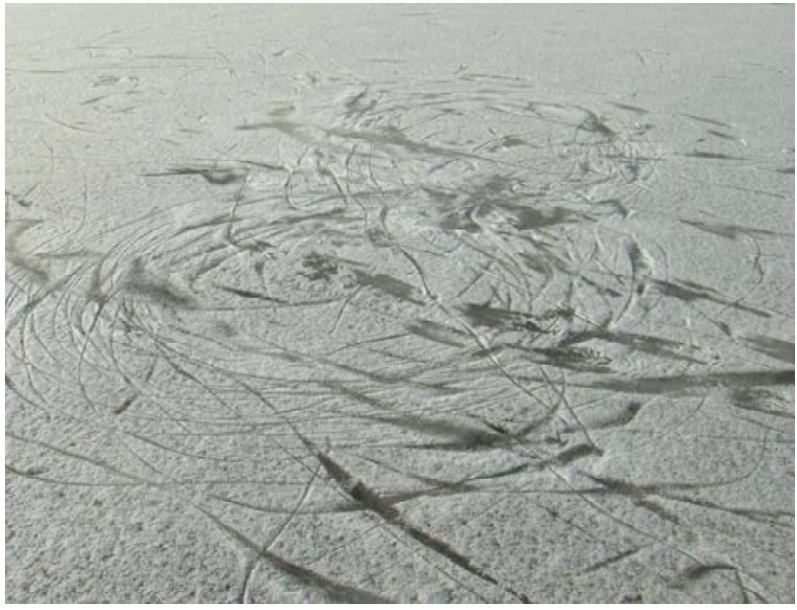

Yani, ben demektir. Ek alır, benim olur, minun olur. 'Puoli'ise yarısı anlamındadır. 'Minun puoli', benim yarım anlamındadır. Bunu evli eşler birbirlerine söylerler Finlandiya'da. Yani giderek eşler bir bütünün ayrılmaz yarısı olurlar. Akademiye girdiğimizde işte böyle bir iki yarıyı beraber tanıdık, yaklaşık 35 - 36 yıl önce. Nursel Hoca ve Muammer Hoca. Çok öğrendiğimiz, iki dünya oldular. Birinin bırakıp diğerinin aldı ̆̆ı, tamamladığı dünya. Biri, birinin yarısı, birbirlerinin yarısı, özel köşelerinin yarısı, ikisi bir bütünün yarısı. 'Minun puoli'lerin dünyası. Hocanın dünyasının yarısı Nursel Ablanındır. Nursel Ablanınkinin de yarısı hocanın.
Zorbada ondan. Kitapta Usta olmadan Zorba, Zorba olmadan Usta olamaz. Bir elmanın yarısıdırlar sanki. Usta Zorba'yı, Zorba ustasını bulmuştur. Yukarıda sözünü ettiğim anlardan biri işte o başlarda anlattığım Zorba'nın ustasına ettiği laf ile birlikte ateşin etrafında oynama sahnesidir. Net hatırladığım bir diğeri de Zorba'nın adadan ustasına attığı ani mesajdır. Zorba postaneye gider ve ustasına telgraf çeker. Telgraf basittir ve beş kelimeliktir. "Yeşil bir taş buldum gel" der. Ustasını düşündürür. Hoca da aynen böyle öğrencilerinin haberleriyle, onların buldukları yeşil taşları anlamaya çalışır ve onlara bulduklarını tekrar tekrar göstermeye, onlarla birlikte tekrar tekrar keşfetmeye 
çalışır. Çünkü orada aslında mimarlığın çok ötesinde izler, işaretler vardır. Mimarlık adına öğretilenler, öğrenilenler hayatın içine akar, mimarlık hayatın içine taşar. Mimarlık bir oyuna dönüşür. Hatta çocuksu, hayalperest, kimsenin yok edilmediği neşeli bir oyundur. Bu özel köşede, bir masanın başında yüz yüze konuşulan mimarlıktır ama aslında öğrenilen belki de mimarlık değil yaşamın ta kendisidir.

\section{Buz}

Son iki paragrafta, yazıya başladığım noktaya, Finlandiya’ya geri dönüyorum. Hepimizin uçarı çizgilerinden, mimari dalgalarından bildiğimiz Aalto'nun ülkesinde, abartılı mevsimlerin vatanı Finlandiya'da, her an değişik doğa oyunlarıyla karşı karşıyasınızdır. Benim de içlerinde yaşadığım işte o ülkenin insanları, her yıl bunlardan çok özel bir tanesine, kışın her yeri kaplayan buz seremonisine tanık olurlar. Sanki konuşulmadan konuşulan, sessizliğin ülkesinde, 1şı ̆̆ın ve gölgenin beraberliği bir başkadır buzla birlikte. Buzun gelişi farklı renkleri ile kışa damgasını vurmuştur yine. Buz yavaş yavaş kıyıları, gölleri, nehirleri sarar, yavaş yavaş kalınlaşır gün ve gün. Yeni buz haritaları çıkar gazetelerde. Bir heykeltıraşın bütün doğayı, kıyıları sabırla kat kat kalıba dökmesi gibidir yavaş yavaş yayılması. Kalındır buz, bir ya da iki karış. Büyük jeepler, arabalar, suların göllerin üzerini aşar ve adalardaki evlere ulaşır. Kentlerin, doğanın sınırları değişir, özgürdür artık insanlar, sınırlara bağlı olmadan. İşte sevgili Muammer Hoca'nın kendi köşesinde yıllarca yarattığı dünya böyle bir şeydir. Yani herkesin her öğrencinin kendi sınırlarını bulduğu, belirlenmiş kalıpları unuttuğu, hatta bir kenara fırlatıp attı̆̆ı, sınırları aşıp kendi sınırlarını koyduğu, buzların gelmesi, ağır ağır yayılması gibidir. Herkesin kendi özel dünyasını bulduğu bir köşedir. Ve sonunda her yıl buzlar çözülür ve yavaş yavaş erir. Ama hala seremonileri akıllardadır bir sonraki kışa kadar. Yani okulu, okuldaki mimarlık eğitimini bitirmemize benzer. Ama nerede olursanız olun her zaman kullanacağınız, herkese göre farklı bir anahtar vardır cebinizde artık eğer atölyede gerçekten ne olduğunu anladıysanız. Herkesin anahtarı da farklıdır; özel ve kişiye özgüdür. Ve her şeyin ötesinde mimarlığ 1 çok sevmişsinizdir. İster mimarlığ öğretin, ister mimarlı̆̆ çizin ve inşa edin, ister mimarlığı konuşun ve yazın, türlü türlü mal sahiplerine, türlü türlü yönetmeliklere, belediye ve oda kurallarına, her şeye karşın, sizin ile mimarlığınız aranıza kolay kolay kimsenin giremeyeceği özel bir hobi olmuştur. Mimarlık denilen şey özel bir yeriniz, özel köşeniz olmuştur artık. Bu bir bayrak yarışıdır. Hocanın bakanı kendisine, bakanları birbirine ve size sizi gösterdiği çok boyutlu ayna, başkalarına göstermeniz için artık ellerinizdedir.

Aynaların dansı sürer gider.

Helsinki, 3 Nisan 2009 